\title{
ANALISIS FAKTOR - FAKTOR YANG MEMPENGARUHI STRUKTUR MODAL PERUSAHAAN CREDIT AGENCY SELAIN BANK DI BURSA EFEK INDONESIA UNTUK PERIODE TAHUN 2011-2015
}

\author{
Ermaini, Arniwita \\ Sekolah Tinggi Ilmu Ekonomi Muhammadiyah Jambi
}

\begin{abstract}
This study aimed to determine the effect of profitability and dividend payout ratio of capital structure in the non-financial listed companies in Indonesia Stock Exchange in 2011-2015. In theory, determining the factors that affect the capital structure based on the pecking order theory. This study included 10 non-financial firms using quantitative research where research data is derived from secondary data obtained from a non-participant observation study documentation. Were treated with multiple linear regression techniques. The analysis showed that profitability significantly and negatively related to capital structure while the dividend payout ratio has no significant effect on capital structure.
\end{abstract}

Keywords: capital structure, dividend payout ratio, profitability

\section{PENDAHULUAN}

Suatu perusahaan dalam menjalankan usahanya sejalan dengan perkembangan yang dialami selalu membutuhkan modal yang digunakan untuk membiayai dalam kegiatan operasional perusahaan itu sehari-hari, baik untuk melakukan investasi maupun untuk keperluan yang lainnya. Besar kecilnya modal yang dibutuhkan oleh suatu perusahaan tergantung dari besar kecilnya biaya akan dikeluarkan oleh perusahaan itu sendiri.

Suatu perusahaan dalam menjalankan usahanya sejalan dengan perkembangan yang dialami selalu membutuhkan modal yang digunakan untuk membiayai dalam kegiatan operasional perusahaan itu sehari-hari, baik untuk melakukan investasi maupun untuk keperluan yang lainnya. Besar kecilnya modal yang dibutuhkan oleh suatu perusahaan tergantung dari besar kecilnya biaya akan dikeluarkan oleh perusahaan itu sendiri. Modal ( Capital ) adalah dana yg digunakan untuk membiayai pengadaan asset dan operasional suatu perusahaan. Modal dapat dilihat di neraca sisi kanan: hutang, saham biasa, saham preferen dan laba ditahan.

Keputusan pendanaan perusahaan terkait keputusan tentang bentuk dan komposisi sumber dana yang akan dipergunakan oleh perusahaan (Husnan dan Pudjiastuti, 2002:277). Struktur modal merupakan komposisi ekuitas dan hutang pada suatu perusahaan yang sering dihitung berdasarkan besaran relatif berbagai sumber pendanaan. Dalam prakteknya, manajer perusahaan bertugas mengidentifikasi stuktur modal yang optimal dengan meminimalkan biaya keuangan perusahaan dan memaksimalkan laba perusahaan (Zeitun dan Tian, 2007).

Ada banyak faktor yang memengaruhi struktur modal dan menentukan stuktur modal yang optimal bukanlah ilmu pasti. Perusahaan yang berada di dalam industri yang sama sekalipun sering memiliki perbedaan struktur modal yang signifikan. Untuk perusahaan keuangan terutama bank masalah struktur permodalan diatur pada peraturaan Bank Indonesia, sehingga penggunaan hutang pada bank dibatasi karena bank harus menyediakan modal minimum sesuai dengan penilaian Bank Indonesia terkait profil risiko bank itu 
sendiri. Berbeda dengan perusahaan keuangan, perusahaan non keuangan lebih fleksibel dalam pemilihan hutang dan modal pada keputusan struktur modal perusahaan karena tidak terikat peraturan Bank Indonesia terkait penyediaan modal minimum. Terdapat dua kriteria dalam keputusan struktur modal (Sartono, 200:186) yaitu meminimalkan wacc dan memaksimalkan nilai perusahaan. Biaya modal rata-rata tertimbang (wacc) dapat diminimumkan apabila perusahaan memutuskan untuk menggunakan lebih banyak hutang (Brigham dan Houston, 2006:488). Namun perlu diperhatikan penggunaan dana ekternal (hutang) menimbulkan risiko apabila perusahaan tidak mampu membayar hutang-hutangnya maka perusahaan terancam likuiditasnya sehingga pada akhirnya mengancam posisi manajer (Yeniatie dan Destriana, 2010).

Menurut Brigham dan Houston (2011:188) perusahaan pada umumnya mempertimbangkan beberapa faktor ketika melakukan keputusan pendanaan. Dalam jurnal Niu (2008) juga memberikan review tentang teori dan praktek dalam penentuan struktur modal. Terdapat faktor yang mempengaruhi struktur modal berdasarkan teori-teori struktur modal. Salah satu teori struktur modal tersebut yaitu teori pecking order. Teori pecking order menjelaskan tentang hierarki pendanaan perusahaan mulai dari yang teraman yaitu perusahaan mendahulukan penggunaan pendanaan internal. Myers (2001) mengungkapkan struktur modal perusahaan berdasarkan pecking order theory terbentuk dari penggunaan pendanaan internal serta kebijakan dividen perusahaan. Pendanaan internal perusahaan identik dengan profitabilitas perusahaan. Perusahaan dengan profitabilitas tinggi akan menggunakan dana internal yang berwujud laba ditahan setelah itu hutang bila memang perlu untuk memenuhi keputusan pendanaan perusahaan. Kebijakan dividen perusahaan dapat memengaruhi keputusan stuktur modal atau sebaliknya, sekaligus dapat menunjukkan nilai perusahaan kepada shareholders (Murekefu dan Ouma, 1857). Dividend payout ratio merupakan bentuk kebijakan dividen perusahaan untuk menentukan jumlah laba yang ditahan serta memaksimalkan nilai perusahaan (Joni dan Lina, 2010). Jadi dari pecking order theory melahirkan variabel profitabilitas dan dividend payout ratio sebagai variabel yang berpengaruh terhadap struktur modal.

Leasing atau sewa-guna-usaha atau bisa juga disebut credit agency selain bank adalah setiap kegiatan pembiayaan perusahaan dalam bentuk penyediaan barang-barang modal untuk digunakan oleh suatu perusahaan untuk jangka waktu tertentu, berdasarkan pembayaran-pembayaran secara berkala disertai dengan hak pilih bagi perusahaan tersebut untuk membeli barang-barang modal yang bersangkutan atau memperpanjang jangka waktu leasing berdasarkan nilai sisa uang yang telah disepakati bersama. Dengan melakukan leasing perusahaan dapat memperoleh barang modal dengan jalan sewa beli untuk dapat langsung digunakan berproduksi, yang dapat diangsur setiap bulan, triwulan atau enam bulan sekali kepada pihak lessor.

Melalui pembiayaan leasing perusahaan dapat memperoleh barang-barang modal untuk operasional dengan mudah dan cepat. Hal ini sungguh berbeda jika kita mengajukan kredit kepada bank yang memerlukan persyaratan serta jaminan yang besar. Bagi perusahaan yang modalnya kurang atau menengah, dengan melakukan perjanjian leasing akan dapat membantu perusahaan dalam menjalankan roda kegiatannya. Setelah jangka leasing selesai, perusahaan dapat membeli barang modal yang bersangkutan. Perusahaan yang memerlukan sebagian barang modal tertentu dalam suatu proses produksi secara tibatiba, 
tetapi tidak mempunyai dana tunai yang cukup, dapat mengadakan perjanjian leasing untuk mengatasinya. Dengan melakukan leasing akan lebih menghemat biaya dalam hal pengeluaran dana dibanding dengan membeli secara tunai. Di Indonesia leasing baru dikenal melalui surat keputusan bersama Menteri Keuangan dan Menteri Perdagangan.

Berdasarkan data BEI, bahwa pada tahun 2011 sampai tahun 2015 tercatat sebanyak 10 perusahaan yang termasuk dalam kelompok IndustrI Credit Agency selain bank, seperti ditunjukkan dalam table 1.1 Daftar Perusahaan Credit Agency Selain Bank 2011-2015.

Tabel 1.1

Daftar Perusahaan Credit Agency Selain Bank di BEI Periode 2011-2015

\begin{tabular}{clc} 
No & \multicolumn{1}{c}{ Industri } & Code \\
& & \\
\hline 1 & PT. Adira Dinamika Multi Fin Tbk & ADM \\
2 & PT.Mandala Multi Fin Tbk & MMF \\
3 & PT. BFI Finance Indonesia Tbk & BFI \\
4 & PT. Buana Finance Tbk & BNF \\
5 & PT. Capitalinc Investment Tbk & CPI \\
6 & PT. Sinar Mas Multiartha Tbk & SMM \\
7 & PT. Clipan Finance Indonesia Tbk & CFI \\
8 & PT. Verena Oto Fin Tbk & VOF \\
9 & PT. Equity Development Invest Tbk & EDI \\
10 & PT. Wahana Ottomitra Multi Tbk & WOM \\
\hline
\end{tabular}

Sumber : ICMD 2007-2009

Tabel diatas menunjukkan bahwa 10 perusahaan tersebut cukup kuat sehingga mampu masuk dalam perusahaan terbuka di BEI. Perbedaan kondisi perusahaan-perusahaan industry credit agency tersebut diatas dipengaruhi factorfaktor struktur modal dan sumber pendanaan perusahaan yang tidak sama, tergantung pada kondisi dan jenis perusahaan. Keputusan dalam penentuan struktur modal sangat di pengaruhi oleh karakteristik di mana perusahaan tersebut berada dan keunikan dari perusahaan secara individu perusahaan. Apapun keputusan yang di ambil akan sangat berpengaruh terhadap nilai keuangan perusahan

Sejalan dengan perkembangan waktu dan perekonomian Indonesia permasalahan yang melibatkan leasing semakin banyak dan kompleks. Mulai dari jenis leasing yang paling sederhana sampai yang rumit. Perbedaan jenis leasing menyebabkan perbedaan dalam pengungkapan laporan keuangan, perlakuan pajak dan akibatnya pada pajak penghasilan badan akhir tahun.Munculnya industry credit agency selain bank merupakan alternatif yang menarik bagi para pengusaha karena saat ini mereka cenderung menggunakan dana rupiah tunai untuk kegiatan operasional perusahaan. Melalui industry credit agency mereka bisa memperoleh dana untuk membiayai pembelian barang-barang modal dengan jangka waktu pengembalian antara tiga tahun hingga lima tahun atau lebih. Disamping hal tersebut di atas para pengusaha juga memperoleh keuntungan-keuntungan lainnya seperti kemudahan dalam pengurusan, dan adanya hak opsi.

Sebagai sesama industri keuangan, perkembangan industri leasing relatif tertinggal dibandingkan yang lain, perbankan, misalnya. Terlebih lagi bila 
dibandingkan dengan perbankan pasca Pakto 1988. Deregulasi yang digulirkan pemerintah di bidang perbankan telah membuahkan banyak sekali bank tetapi juga menyebabkan suramnya industri perbankan di kemudian hari. Puncaknya, terjadi pada 1996 ketika pemerintah melikuidasi 16 Bank. Langkah itu ternyata masih diikuti dengan dimasukkannya beberapa bank lain dalam perawatan Badan Penyehatan Perbankan Nasional (BPPN). Dampak likuidasi 16 Bank terhadap industry credit agency masih terasa hingga kini.

Ada beberapa hal menarik jika kita mencermati konsentrasi dan perkembangan perusahaan di industry credit agency. Pada era 1989, misalnya, industri ini di Indonesia cenderung berupaya memperbesar asset. perburuan asset tersebut diantaranya disebabkan tantangan perekonomian menuntut mereka tampil lebih besar, sehat dan kuat. Perusahaan yang tidak beranjak dari skala semula, tampak terguncang-guncang dana akhirnya tutup sama sekali.

Berdasarkan studi kepustakaan ditemukan banyak penelitian terkait dengan faktor- faktor yang memengaruhi struktur modal. Penelitian satu dengan penelitian lain memeroleh hasil yang beragam dan tidak konsisten. Febriyani dan Srimindarti (2010) mendapatkan kesimpulan bahwa profitabilitas berpengaruh negatif terhadap struktur modal. Hasil tersebut serupa dengan hasil penelitian Yuliati (2011), Santika dan Sudiyatno (2011), Prabansari dan Kusuma (2007), Sofilda dan Maryani (2007), Frank dan Goyal (2010), Hijazi dan Tariq (2006) dan Mishra (2011). Ruslim (2009) menguji stuktur modal (teori pecking order) di saham LQ45 memeroleh hasil bahwa profitabilitas memiliki pengaruh negatif namun tidak signifikan terhadap struktur modal. Hasil ini serupa dengan hasil penelitian Erickson dan Trevino (1994) dan Ogbulu dan Emeni (2012). Putri (2012) mendapat hasil profitabilitas justru memiliki pengaruh positif tetapi tidak signifikan terhadap struktur modal perusahaan manufaktur industri makanan dan minuman di BEI. Jensen et.al (1992) meneliti pengaruh antara insider ownership, debt dan dividend policies. Penelitian dilakukan dengan metode cross section dengan tahun 1982 dan 1987 sebagi tahun penelitian.

Hasil yang didapat insider ownership dan dividend policies berpengaruh negatif terhadap debt. Faulkender et.al (2006) mendapat kesimpulan pada penelitian mengenai capital structure dan dividend policy bahwa perusahaan cenderung menurunkan penggunanaan hutang melalui dividend payout ratio yang rendah. Sehingga dividend payout ratio berpengaruh negatif terhadap struktur modal. Ince dan Owers (2009) menyebutkan bahwa terdapat hubungan positif antara struktur modal dengan kebijakan dividen perusahaan. Franc- Dabrowska (2009) meneliti hubungan antara 2 teori struktur modal yaitu hierarchy theory dan substitution theory dengan kebijakan pembayaran dividen pada perusahaan polish sektor agricultural dan foodstuff yang terdaftar di Warsaw Stock Exchange tahun 2001-2006. Hasil yang didapat bahwa kebijakan pembayaran dividen pada perusahaan-perusahaan tersebut menunjukan tipe hubungan dari hierarchy theory. Manajemen perusahaan lebih memilih sumber internal untuk aktivitas keuangan, di saat yang bersamaan mereka membatasi pembayaran dividen.

Myers (2001) mengungkapkan struktur modal perusahaan berdasarkan pecking order theory yaitu:

1. Perusahaan lebih menyukai pendanaan dari dalam. (karena asimetris informasi diasumsikan relevan hanya pada pendanaan dari luar

2. Dividen adalah sticky dimana pembayaran dividen akan memiliki kecenderungan yang konstan. 
3. Apabila perusahaan harus menggunakan pendanaan eksternal, maka sekuritas yang paling aman dipilih terlebih dahulu. Apabila memerlukan pendanaan dari luar yang lebih banyak, maka urutan pendanaan mengikuti pecking order.

4. Debt ratio di tiap perusahaan mencerminkan akumulasi dari jumlah pendanaan luar/eksternal.

Berdasarkan landasan teori dan hasil-hasil penelitian terdahulu yang telah dipaparkan, hipotesis yang dikembangkan adalah sebagai berikut:

1. Rofitabilitas

Teori pecking order menyebutkan bahwa perusahaan menyukai internal fund, kemudian dana eksternal, dan akhirnya ekuitas eksternal. Teori ini mengimplikasikan bahwa profitabilitas perusahaan yang lebih tinggi dominan memaanfaatkan internal fund. Tingginya tingkat pengembalian dari kegiatan investasi dan operasi membuat perusahaan dapat membiayai sebagian besar kebutuhan pendanaan dengan internal fund. H1 : Profitabilitas berpengaruh negatif terhadap stuktur modal.

\section{Dividend Payout Ratio}

Kebijakan deviden dapat menjadi signal bagi investor untuk menilai kinerja perusahaan, hal ini disebabkan karena kebijakan dividen berdampak terhadap harga saham perusahaan (Mardiyati,dkk., 2012). Dividend payout ratio yang lebih tinggi akan menaikkan profitabilitas perusahaan dengan konsekuensi bahwa perusahaan harus mencari dana eksternal (Sartono, 2000:257). H2 : Dividend Payout Ratio berpengaruh positif terhadap stuktur modal

Berangkat dari latar belakang diatas maka peneliti tertarik untuk melakukan penelitian yang diberi judul "Analisis Faktor-Faktor Yang Mempengaruhi Struktur Modal industry Credit Agency Selain Bank Di Bursa Efek Indonesia untuk periode tahun 2011-2015

Penelitian ini bertujuan untuk : 1) Menganalisis pengaruh operating leverage terhadap struktur modal yang dicerminkan dalam debt equity ratio untuk periode 2011-2014? 2) Menganalisis pengaruh likuiditas terhadap struktur modal yang dicerminkan dalam debt equity ratio untuk periode 2011-2014? 3) Menganalisis pengaruh struktur aktiva terhadap struktur modal yang dicerminkan dalam debt equity ratio untuk periode 2011-2014? 4) Menganalisis pengaruh pertumbuhan perusahaan terhadap struktur modal yang dicerminkan dalam debt equity ratio untuk periode 2011-2014? 5) Menganalisis pengaruh price Earning ratio terhadap struktur modal yang dicerminkan dalam debt equity ratio untuk periode 20112014? 6) Menganalisis pengaruh profitabilitas terhadap struktur modal yang dicerminkan dalam debt equity ratio untuk periode 2011-2014? 7) Menganalisis pengaruh Operating leverage, Likuiditas, struktur Aktiva, pertumbuhan perusahaan, Price Earning Ratio dan Profitabilitas secara bersama-sama terhadap struktur modal yang dicerminkan dalam debt equity ratio untuk periode 20112014 ?

Penelitian ini di harapkan mempunyai manfaat antara lain : 1) Bagi para pemakai laporan keuangan ( terutama investor dan kreditor ) dalam rangka menilai kinerja perusahaan yang tercermin dalam struktur modal (debt to equity ratio), sehingga dapat digunakan sebagai dasar pengambilan keputusan dalam pemberian pinjaman kepada perusahaan . 2) Bagi pihak manajemen dapat digunakan sebagai bahan pertimbangan untuk menentukan besarnya sumber dana 
yang diperlukan (baik dari pinjaman ataupun ekuitas) dalam membiayai aktivitas operasional perusahaan.

\section{METODOLOGI PENELITIAN}

\section{Jenis dan Sumber Data}

Jenis data yang digunakan adalah data sekunder. Data sekunder berupa laporan keuangan tahunan suatu perusahaan.

Data-data yang diperlukan antara lain adalah data industry credit agency selain bank yang terdaftar di Bursa Efek Indonesia dan laporan keuangan tahunan perusahaan diperoleh dari Indonesian Capital Market Directory.

\section{Teknik Analisis}

Untuk menjelaskan kekuatan dan arah pengaruh beberapa variabel bebas atau variabel penjelas (independent/ explanatory variable) terhadap satu variable terikat (dependent variable), teknik analisis data dalam penelitian ini menggunakan model regresi berganda atau Multiple Regression (Imam Ghozali, 2001).

\section{Pengujian Asumsi Klasik}

Dalam penggunaan model regresi berganda, uji hipotesis harus menghindari adanya kemungkinan terjadinya penyimpangan asumsi-asumsi klasik. Dalam penelitian ini, asumsi klasik yang dianggap paling penting adalah (Gujarati, 1995):
a. Memiliki distribusi normal,
b. Tidak terjadi Multikolinieritas antar variabel independen,
c. Tidak terjadi Heteroskedastisitas atau varian variabel penggangu yang konstan (Homoskedastisitas),
d. Tidak terjadi Autokorelasi antar residual setiap variabel independen.

\section{Uji Normalitas}

Uji normalitas bertujuan untuk menguji apakah dalam sebuah regresi, variabel dependen, variabel independen atau kedua-duanya mempunyai distribusi normal ataukah tidak. Model regresi yang baik adalah memiliki distribusi data normal atau mendekati normal (Santoso, 2000).

Pada Uji Normalitas Data ini menggunakan metode One Sample Kolmogorov-Smirnov Test. Pemilihan metode ini didasarkan bahwa One Sample Kolmogorov-Smirnov Test merupakan metode yang umum digunakan untuk menguji normalitas data (Hair,et al, 1998). Tujuan pengujian ini adalah untuk mengetahui apakah sampel yang digunakan dalam penelitian ini berdistribusi normal atau tidak. Untuk mengetahuinya hasilnya, dengan analisa:

a. Jika nilai probabilitas $>$ taraf signifikansi yang ditetapkan $(\alpha=0,05)$, maka model regresi memenuhi asumsi normatilitas.

b. Jika nilai probabilitas $>$ taraf signifikansi yang ditetapkan $(\alpha=0,05)$, maka model regresi tidak memenuhi asumsi normatilitas.

\section{Uji Multikolinieritas}

Uji Multikolinieritas dilakukan untuk menguji apakah dalam model regresi ditemukan adanya korelasi antar variabel bebas atau independen (Santoso, 2000). Jika terjadi korelasi, maka dinamakan terdapat problem Multikolinieritas. Model regresi yang baik seharusnya tidak terjadi korelasi di antara variabel bebas. Adanya Multikolinieritas dalam model persamaan regresi yang digunakan akan mengakibatkan ketidakpastian estimasi, sehingga mengarah pada kesimpulan yang menerima hipotesis nol. Hal ini menyebabkan koefisien regresi menjadi tidak signifikan (Gujarati, 1995). 
Salah satu metode untuk menguji ada tidaknya Multikolinieritas pada penelitian ini adalah dengan melihat (Santoso, 2001):

a. Besaran VIF (Variance Inflation Factor) dan Tolerance.

Pedoman suatu model regresi yang bebas multiko adalah:

1) mempunyai nilai VIF di sekitar angka 1

2) mempunyai angka TOLERANCE mendekati 1

catatan: Tolerance $=1 / \mathrm{VIF}$ atau VIF $=1 /$ Tolerance

b. Besaran korelasi antar variabel independen.

Pedoman suatu model regresi yang bebas multiko adalah Koefisien korelasi antar variable independen haruslah lemah (di bawah 0,5). Jika korelasi kuat, maka terjadi problem multiko.

\section{Uji Heteroskedastisitas}

Uji Heteroskedastisitas digunakan untuk menguji apakah pada model regresi terjadi ketidaksamaan variabel dari residual satu pengamatan ke pengamatan lainnya. Jika variabel dari residual satu pengamatan ke pengamatan lain tetap, maka disebut Homoskedastisitas dan jika berbeda disebut Heteroskedastisitas. Model regresi yang baik adalah yang Homoskedastisitas atau tidak terjadi Heteroskedastisitas.

Salah satu untuk menguji ada tidaknya Heteroskedastisitas pada penelitian ini adalah dengan menggunakan grafik lewat program SPSS. Dasar pengambilan keputusan (Imam Ghozali, 2001):

a. Jika ada pola tertentu, seperti titik-titik yang membentuk suatu pola yang teratur (bergelombang, melebar kemudian menyempit), maka telah terjadi Heteroskedastisitas.

b. Jika tidak ada pola yang jelas, serta titik-titik menyebar di atas dan di bawah angka 0 pada sumbu Y, maka terjadi Heteroskedastisitas.

\section{Uji Autokorelasi}

Uji Autokorelasi bertujuan menguji apakah dalam suatu model regresi linear ada korelasi antara kesalahan pengganggu pada periode $\mathrm{t}$ dengan kesalahan pada periode t-1 (sebelumnya). Jika terjadi korelasi, maka dinamakan ada problem autokorelasi. Autokorelasi muncul karena observasi yang berurutan sepanjang waktu berkaitan satu sama lain. Masalah ini timbul karena residual (kesalahan pengganggu) tidak bebas dari satu observasi ke observasi lainnya. Hal ini sering ditemukan pada data runtut waktu atau time series karena "gangguan" pada individu atau kelompok cenderung mempengaruhi individu atau kelompok pada periode berikutnya. Model regresi yang baik adalah regresi yang bebas dari autokorelasi.

Pada penelitian ini, gejala autokorelasi dideteksi penulis dengan menggunakan Uji Durbin-Watson lewat SPSS. Pengambilan keputusan ada tidaknya Autokorelasi ditentukan berdasarkan kriteria berikut (Imam Ghozali, 2001):

a. Bila nilai DW terletak antara batas atas atau upper bound (du) dan (4-du), maka koefisien autokorelasi sama dengan nol, berarti tidak ada autokorelasi.

b. Bila nilai DW lebih rendah daripada batas bawah atau lower bound (dl), maka koefisien autokorelasi lebih besar daripada nol, berarti ada autokorelasi positif.

c. Bila nilai DW lebih besar daripada (4-dl), maka koefisien autokorelasi lebih kecil daripada nol, berarti ada autokorelasi negatif. 
d. Bila nilai DW terletak di antara batas atas (du) dan batas bawah (dl) atau DW terletak antara (4-du) dan (4-dl), maka hasilnya tidak dapat disimpulkan.

\section{Deskripsi Statistik}

Mengulas tentang data-data statistik dari masing-masing variabel seperti:
a. Mean, yaitu rata-rata dari nilai data penelitian
b. Standar deviasi, yaitu besarnya varians/ perbedaan nilai antara nilai data minimal dan maksimal.
c. Nilai maksimum, yaitu nilai tertinggi dari data penelitian.
d. Nilai minimum, yaitu nilai terendah data penelitian.
Dalam penelitian ini akan diulas mengenai variabel total aktiva, total ekuitas, total hutang, laba bersih, keuntungan per lembar saham dan harga penutupan per lembar saham. Perhitungan data-data statistik dari masing- masing variabel tersebut menggunakan program SPSS.

\section{Uji Hipotesis}

Uji ini digunakan untuk menjelaskan kekuatan dan arah pengaruh beberapa variabel bebas (independent variable) terhadap satu variabel terikat (dependent variable).

Teknik analisis data dalam penelitian ini menggunakan model regresi berganda atau Multiple Regression (Imam Ghozali, 2001) yang akan diolah dengan menggunakan program komputer SPSS 10.0. Hubungan antara variable dependen (Y) dengan variabel independen (X) dijelaskan dalam model regresi berganda (multiple regression model) adalah :

$\mathrm{Y}=\mathrm{f}(\mathrm{X} 1, \mathrm{X} 2, \ldots . ., \mathrm{Xn})$

Sedang persamaan regresi bergandanya menjadi:

$\mathrm{Y}=\mathrm{a}+\mathrm{b} 1 \mathrm{X} 1+\mathrm{b} 2 \mathrm{X} 2+\ldots . .+\mathrm{bn} \mathrm{Xn}$

Dimana:

a. Y adalah variabel dependen, a adalah nilai $\mathrm{Y}$ pada perpotongan antara garis linear dengan sumbu vertikal $Y /$ nilai $Y$ ketika semua $X=0$.

b. $-\mathrm{X} 1, \mathrm{X} 2, \ldots, \mathrm{Xn}$ adalah variabel independen 1,2, dan ke-n.

c. b adalah kemiringan (slope) yang berhubungan dengan variabel X1, X2,., Xn.

Dalam penelitian ini, persamaan regresinya menjadi:

$\mathrm{DER}=\beta_{0}+\beta_{\mathrm{DOL}} \mathrm{X}_{\mathrm{DOL}}+\beta_{\mathrm{CR}} \mathrm{X}_{\mathrm{CR}}+\beta_{\mathrm{ASSET}} \mathrm{X}_{\mathrm{ASSET}}+\beta_{\mathrm{GROW}} \mathrm{X}_{\mathrm{GROW}}+\beta_{\mathrm{PER}} \mathrm{X}_{\mathrm{PER}}+\beta_{\mathrm{ROA}} \mathrm{X}_{\mathrm{ROA}}$

dimana:

DER = Debt to Equity Ratio

$\mathrm{X}_{\mathrm{DL}} \quad=$ Operating Leverage

$\mathrm{X}_{\mathrm{CR}} \quad=$ Current Ratio

$\mathrm{X}_{\mathrm{ASSET}} \quad=$ Struktur Aktiva

$\mathrm{X}_{\mathrm{GROW}} \quad=$ Pertumbuhan Perusahaan

$\mathrm{X}_{\mathrm{PER}} \quad=$ Price Earning Ratio

$\mathrm{X}_{\mathrm{ROA}} \quad=$ Return On Assets

Uji Hipotesis dilakukan sebagai berikut: uji signifikansi (pengaruh nyata) variabel independen $(\mathrm{Xi})$ terhadap variabel dependen $(\mathrm{Y})$ baik secara parsial maupun secara bersama-sama, dilakukan uji statistik $\mathrm{t}(t-$ test $)$ dan uji $\mathrm{F}$. 


\section{Uji $\mathbf{t}$ - statistik}

Uji keberartian koefisien ( $\beta \mathrm{i})$ dilakukan dengan statistik t. Hal ini digunakan ntuk menguji koefisien regresi secara parsial dari variabel independen mengetahui apakah masing-masing variabel independen secara signifikan berpengaruh terhadap variabel dependen).

Dasar pengambilan keputusannya adalah melakukan analisis dengan program SPSS. Jika koefisien signifikan $\mathrm{t}(\beta \mathrm{i})<$ taraf signifikansi yang telah ditetapkan $(\alpha=5 \%)$, maka secara parsial variabel independen tersebut berpengaruh signifikan terhadap variabel dependen, sehingga H0 ditolak (Imam Ghozali, 2001).

\section{Uji F - statistik}

Uji F - statistik digunakan untuk menguji keberartian pengaruh dari seluruh variabel independen secara bersama - sama terhadap variabel dependen. Dasar pengambilan keputusannya adalah melakukan analisis dengan program SPSS. Dengan program SPSS, uji Anova atau F test, bila didapatkan koefisien signifikan $\mathrm{t}(\beta \mathrm{i})<$ taraf signifikansi yang telah ditetapkan $(\alpha=5 \%)$, maka model regresi bisa dipakai untuk memprediksi variabel dependen (Imam Ghozali, 2001).

\section{SIMPULAN DAN SARAN Simpulan}

Dari hasil analisis yang dilakukan, profitabilitas berpengaruh negatif dan signifikan terhadap struktur modal perusahaan non keuangan yang terdaftar di Bursa Efek Indonesia tahun 2011-2015 namun berbeda dengan dividend pauout ratio yang tidak berpengaruh secara signifikan terhadap struktur modal karena perusahaan yang menjadi sampel tidak selalu membagikan dividen di tiap periodenya ataupun dividen yang dibagikan ke para pemegang saham tidak konstan.

\section{Saran}

1. Bagi pihak manajemen perusahaan non keuangan, apabila pihak manajemen ingin meminimalkan penggunaan hutang dapat dilakukan dengan mengefisienkan investasi.

2. Bagi pihak kreditur, apabila ingin menawarkan hutang ke pihak perusahaan dapat mempertimbangkan tingkat profitabilitas perusahaan karena perusaahan yang profitabilitasnya tinggi lebih mampu melakukan pembayaran atas hutang yang dimiliki.

3. Bagi pihak investor, apabila ingin berinvestasi dapat menjadikan profitabilitas perusahaan sebagai tolak ukur keuntungan yang didapat dari investasi tersebut. Investor hendaknya memilih perusahaan dengan tingkat hutang yang minimal sebab semakin besar hutang maka semakin besar juga resiko yang akan ditanggung oleh investor karena kemungkinan perusahaan tidak mampu membayar hutang-hutangnya.

4. Penelitian selanjutnya diharapkan dapat dilakukan dengan sampel perusahaan keuangan agar dapat membandingkan hasil yang didapat dari kedua variabel bebas yaitu profitabilitas dan dividend payout ratio terhadap struktur modal perusahaan non keuangan dengan perusahaan keuangan

\section{DAFTAR PUSTAKA}

Agus Eko Sujianto, 2001, “Analisis Variabel-variabel yang mempengaruhi struktur keuangan pada perusahaan Manufaktur yang Go Publik di Bursa 
Efek Jakarta”, Jurnal Ekonomi dan Manajemen, Vol.2, No.2, Desember 2001, Hal.125 - 138.

Ang, Robbert. (1997). "Buku Pintar: Pasar Modal Indonesia (The Intelligent Guide to Indonesian Capital Market)". Mediasoft Indonesia

Bathala, C.T., K.R. Moon, and R.P. Rao. (1994). "Managerial Ownership, DebtPolicy, and the Impact of Institutional Holding: an Agency Perspective".Financial Management, 23: 38 - 50.

Brigham, Eugene F. (1983). “Fundamentals of Financial Management”. Third Edition. Holt-Saunders Japan: The Dryden Press.

Bushman, Robert M. (2001). "Financial Accounting Information and Corporate Governance”. Journal of Accounting \& Economics, 32 (2001): 237-333.

Crutchley, Claire E., and Hansen, Robert S. (1989). "A test of the Agency Theory of Managerial Ownership, Corporate Leverage, and Corporate Dividend". Financial Management, Winter 1989.

Eugene F. Brigham \& Louis C.Gapenski, 1996, Intermediate FinancialManagement, Fifth edition-International edition, The Dryden Press

Fitrijanti, Tettet dan Hartono, Jogiyanto. (2002). "Set Kesempatan Investasi: Konstruksi dan Analisis Hubungannya dengan Kebijakan Pendanaan dan Dividen". Jurnal Riset Akuntansi Indonesia, Vol. 5, No. 1:35- 63.

Gujarati, Damodar N. (1995). “Basic Econometrics”. Singapore: Mc Graw Hill, Inc.

Hartono, Jogiyanto. (1998). "Teori Portofolio dan Analisis Investasi". Yogyakarta: BPFE.

Hermendito Kaaro, Analisis leverage dan Deviden dalam lingkungan ketidakpastian: Pendekatan Pecking Order dan Balancing Theory, Simposium Nasional Akuntansi IV

Husnan, Suad. (2001). "Corporate Governance dan Keputusan Pendanaan: Perbandingan Kinerja Perusahaan dengan Pemegang Saham Pengendali Perusahaan Multinasional dan Bukan Multinasional". Jurnal Riset Akuntansi, Manajemen, Ekonomi, Vol. 1 No.1, Februari: 1 - 12.

J. Fred Weston \& Thomas Copeland, 1997, Manajemen Keuangan, Jilid 2, Edisi 9, Binarupa Aksara

Lambert, Richard A. (2001). "Contracting Theory and Accounting". Journal of Accounting \& Economics, 32 (2001): 3- 87.

Lukas Setia Atmaja, 1999, Manajemen Keuangan, Edisi 2, Andi Offset

Myers, S, The Capital Structure Puzle, Journal of Finance, Vol.39. July, 1984

Na'im, Ainun dan Rakhman, Fu'ad. (2000). "Analisis Hubungan antara Kelengkapan Pengungkapan Laporan Keuangan dengan Struktur Modal dan Tipe Kepemilikan Perusahaan”. Jurnal Ekonomi dan Bisnis Indonesia, Vol. 15, No. 1: $70-82$.

Sekar Mayangsari, Analisis Faktor-Faktor yang Mempengaruhi Keputusan Pendanaan Perusahaan : Pengujian Pecking Order Hyphotesis, Media Riset Akuntansi, Auditing dan Informasi, Vol 1, No. 3 Desember 2001:1-26

Wasi aji , Darmawan (2003) "Analisis factor-factor yang mempengaruhi Struktur Modal: 25-26

Kumla sari, Ratna ( 2004) "Anaalisis Pengaruh factor Liquiditas dan Profitabilitas terhadap Struktur Modal perusahaan property"

Singgih Santoso. (1999). SPSS ( Statistical Product and Service Solutions). Penerbit PT. Elex Media Komputindo-Kelompok Gramedia .Jakarta. 
Sofiati, "Pengaruh Timbal Balik antara Utang dan Ekuitas Terhadap Struktur Modal Perusahaan-Perusahaan Go Public di Bursa Efek Jakarta", Kompak, Januari 2001

Suad Husnan, 1998, Manajemen Keuangan-Teori dan Penerapan keputusan jangka panjang), Buku 1, Edisi 4, BPFE. 